\title{
Attitude of Patients towards Student Nurses
}

\section{Pooja Shakya* and Prabha Aryal}

Alka Institute of Medical Sciences, Purbanchal University, Nepal

*Corresponding author: Pooja Shakya, Alka Institute of Medical Sciences, Purbanchal University, Nepal, Tel: +9803538136; E-mail: shakyapooja049@gmail.com Received date: August 13, 2018; Accepted date: August 18, 2018; Published date: August 27, 2018

Copyright: ( 2018 Shakya P, et al. This is an open-access article distributed under the terms of the Creative Commons Attribution License, which permits unrestricted use, distribution, and reproduction in any medium, provided the original author and source are credited.

\begin{abstract}
The present study was conducted to assess the attitude of patients towards student nurses. The descriptive research design was applied for the study where one hundred and fifteen respondents were involved from patients of Alka Hospital. A non-probability purposive sampling technique was for the sample. Interview schedule was developed for the data collection. Ethical consideration was maintained throughout the study. Data was collected by researcher herself. Data were analyzed with the help of Statistical Package for Social Science (SPSS) version 20. The findings of the data were analyzed using different descriptive statistics like frequency, percentage, mean and standard deviation. Results were presented in different academic tables.
\end{abstract}

The study showed 7 percent of the respondents disagree with students acceptance depends on their confidence level whereas 9.6 percent of the respondents strongly disagree that students are skillful and competent in their roles. Furthermore, 60.9 percent of the respondents agree that student's general appearance and manner are important for patient willingness for care. Similarly, least (3.5\%) of the respondents disagree that patient satisfaction influenced with skills of students. Likewise, least $(1.7 \%)$ of the respondents strongly disagree that grade of nursing students differs in patient care. The present study showed that the majority $(73.9 \%)$ of the respondents had negative attitude likewise 24.3 percent of the respondents had positive attitude and only 1.7 percent of the respondents had neutral attitude towards student nurses.

On the basis of the finding of the study it can be concluded that, majority of the respondents had negative attitude, less than half of the respondents had positive attitude whereas minority of the respondents had neutral attitude towards student nurses.

\section{Keywords: Attitude; Patient; Student nurse}

\section{Background of the Study}

Nursing encompasses autonomous and collaborative care of individuals of all ages, families, groups and communities, sick or well and in all setting. It includes the promotion of health, the prevention of illness and the care of ill, disabled and dying people [1]. The mandate of nursing education institution is to prepare and produce nurse capable of rendering nursing care that is appropriate for the health need of society. In order to best prepare these student nurses, they are exposed to hospital-based training in hospital to achieve emotional stamina and comprehensiveness in training [2].

Nursing is a profession within the healthcare sector focused on the care of individuals, families, and communities so they may attain, maintain, or recover optimal health and quality of life. Nurses may be differentiated from other health care provide by their approach to patient care, training and scope of practice. The authority for the practice of nursing is based upon social contracts that delineate professional rights and responsibilities as well as mechanisms for public accountability. In almost all countries, nursing practice is defined and governed by law, and entrance to the profession and is regulated at the national state or state level. There are a number of educational paths to becoming a professional nurse, which vary greatly worldwide; all involve extensive study of nursing theory and practice as well as training in clinical skills. Nurses care for all individuals of all ages and cultural backgrounds who are healthy and ill in a holistic manner based on the individual's physical, emotional, psychological, intellectual, social and spiritual needs [3].

According to the study done by Salah et al. [4] showed that 356 (88.8\%) patients agreed to participate. The highest acceptance rates were found in the situation where there is no direct contact between patient and the students (e.g., when reading their medical files, attending ward round). As the degree of student's involvement increased, the refusal rate increased. Study done in Nigeria, results showed that $71.8 \%$ of respondent had positive attitudes towards the care of older people. It further revealed that respondents (97.2\%) believed that student's nurses should be patient, cheerful and sensitive, as well as empathetic (91.4\%) when caring for the older patients [5].

Similarly, $52 \%$ of the patients felt comfortable with the presence of students, $81.5 \%$ of the patients agreed to be examined by students in the presence of the supervisor, while $40.2 \%$ gave agreement even in the absence of the supervisor. They expressed comfort in general but some expressed concerns over the experienced by students [6]. Eighty-one percent of respondents felt that student's general appearance and manner were important to their willingness to have them participate in their care and $64 \%$ would not object to the presence of students during physical examination. Most (63\%) preferred to be informed about student's involvement beforehand. Fifty-five percent believed that they have right to refused students [7]. Patients were grading their comfort with a student's presence from 0 indicating very comfortable to 10 indicating very uncomfortable. Only $12 \%$ of patients had some degree 
Page 2 of 5

of objection to the presence of student nurses and most patients (72\%) had no preference as to the student's presence [8].

In the context of Nepal, the attitudes towards nurses and nursing profession is relatively poor as compared to other parts of Asian and developed countries. Majority (66.7\%) of nursing students had friendly behavior and then 50 percent subject nurses are helpful, clean and tidy, empathetic, soft spoken and unbiased. Regarding kindness, clever, gentle and respectable they reported the performance level below 50 percent [9]. Sixty percent (60\%) respondents had positive perception of the students nurses performing nursing care to them, $40 \%$ participants had some negative experience of their encounters with the students nurse in their therapeutic relationship [2]. Patient's perception towards quality nursing care give results that the perception of the respondents about nursing care (nurses behavior, safety and security) is positive, as $91 \%$ perceived positively, whereas $9 \%$ perceived negatively. There is no significant difference of perception is relation to total nursing care which concluded that most of the respondents showed positive attitudes towards quality nursing care [10]. Although nursing profession has been always regarded as a valuable profession in developed countries but in Nepal nursing profession mostly being a female occupation was taken as a few status. Parents strictly prohibit their daughter from receiving nursing education. Modern advances technology and medicines have brought dramatic achievement throughout the world [9].

\section{Study Population: Patients Admitted}

\section{Data analysis}

Data was analyzed and interpreted according to objectives and the nature of research questions. All collected data was overviewed, checked and verified for its accuracy and completeness. Data was coded then entered and analyzed with the help of software Statistical Package for Social Science (SPSS) version 20. Different descriptive statistics like frequency, percentage, mean, and standard deviation (Table 1). The finding was presented in different academic tables.

Likert scale was analyzed on the basis of attitude measurement scale by Carmichael et al. [11] in Attitude of Patient towards the Presence of Medical Students in a Breast Clinic (Table 2).

\section{Scoring}

Negative attitude: 1-80.

Neutral attitude: 81 .

Positive attitude: 82-135.

\begin{tabular}{|c|c|c|c|c|c|}
\hline Items & $\begin{array}{l}\text { Agree } \\
\text { N (\%) }\end{array}$ & $\begin{array}{l}\text { Strong } \\
\text { ly } \\
\text { Agree } \\
\text { N (\%) }\end{array}$ & $\begin{array}{l}\text { Neither } \\
\text { agree } \\
\text { nor } \\
\text { disagre } \\
\text { e N (\%) }\end{array}$ & $\begin{array}{l}\text { Strongl } \\
y \\
\text { Disagr } \\
\text { ee } \quad \mathrm{N} \\
(\%)\end{array}$ & $\begin{array}{l}\text { Disagr } \\
\text { ee } \mathrm{N} \\
(\%)\end{array}$ \\
\hline $\begin{array}{l}\text { Students general } \\
\text { appearance and manner are } \\
\text { important to patient } \\
\text { willingness to have them in } \\
\text { care }\end{array}$ & )$^{18(15.7}$ & $\begin{array}{l}18(15 . \\
7)\end{array}$ & $16(13.9)$ & $7(6.1)$ & $4(3.5)$ \\
\hline $\begin{array}{l}\text { Student nurse should be } \\
\text { patience, cheerful and } \\
\text { empathetic while caring }\end{array}$ & $\begin{array}{l}51(44.3 \\
)^{2}\end{array}$ & $\begin{array}{l}25(21 . \\
7)\end{array}$ & $28(24.3)$ & $6(5.2)$ & $5(4.3)$ \\
\hline
\end{tabular}

\begin{tabular}{|l|l|l|l|l|l|}
\hline $\begin{array}{l}\text { Patients satisfaction is } \\
\text { influenced by the } \\
\text { appearance, behavior and } \\
\text { communication skill of } \\
\text { student nurses }\end{array}$ & $\begin{array}{l}64(55.7 \\
)\end{array}$ & $\begin{array}{l}22(19 . \\
1)\end{array}$ & $20(17.4)$ & $5(4.3)$ & $4(3.5)$ \\
\hline $\begin{array}{l}\text { Students nurses are } \\
\text { identified through their dress } \\
\text { code }\end{array}$ & $55(47.8$ & $\begin{array}{l}22(19 . \\
1)\end{array}$ & $26(22.6)$ & $9(7.8)$ & $3(2.6)$ \\
\hline $\begin{array}{l}\text { Dress of student nurses } \\
\text { should be neat, clean and } \\
\text { appropriate }\end{array}$ & $\begin{array}{l}59(51.3 \\
)\end{array}$ & $\begin{array}{l}18(15 . \\
7)\end{array}$ & $16(13.9)$ & $12(10.4$ & $10(8.7)$ \\
\hline
\end{tabular}

Table 1: Respondent's Attitude towards Grooming of Student Nurse.

\begin{tabular}{|l|l|l|l|l|l|}
\hline Items & $\begin{array}{l}\text { Agree N } \\
\text { (\%) }\end{array}$ & $\begin{array}{l}\text { Strongl } \\
\text { y Agree } \\
\text { N (\%) }\end{array}$ & $\begin{array}{l}\text { Neither } \\
\text { agree } \\
\text { nor } \\
\text { disagre } \\
\text { e N (\%) }\end{array}$ & $\begin{array}{l}\text { Strongly } \\
\text { Disagre } \\
\text { e N (\%) }\end{array}$ & $\begin{array}{l}\text { Disagre } \\
\text { e N (\%) }\end{array}$ \\
\hline $\begin{array}{l}\text { Student nurses are } \\
\text { skillful and competent } \\
\text { in their nursing roles }\end{array}$ & $36(31.3)$ & $25(21.7)$ & $29(25.2)$ & $11(9.6)$ & $14(12.2)$ \\
\hline $\begin{array}{l}\text { Student nurses have } \\
\text { more time to give }\end{array}$ & $26(22.6)$ & $27(23.5)$ & $26(22.6)$ & $24(20.9)$ & $12(10.4)$ \\
\hline $\begin{array}{l}\text { I feel enjoy caring and } \\
\text { being student nurse }\end{array}$ & $10(8.7)$ & $21(18.3)$ & $33(28.7)$ & $24(20.9)$ & $27(23.5)$ \\
\hline $\begin{array}{l}\text { Student nurses provide } \\
\text { patients with emotional } \\
\text { support }\end{array}$ & $24(20.9)$ & $26(22.6)$ & $42(36.5)$ & $13(11.3)$ & $10(8.7)$ \\
\hline $\begin{array}{l}\text { *Student nurses } \\
\text { behave badly to the } \\
\text { patients }\end{array}$ & $42(36.5)$ & $19(16.5)$ & $34(29.6)$ & $12(10.4)$ & $8(7)$ \\
\hline $\begin{array}{l}\text { Student nurses should } \\
\text { have good behavior } \\
\text { and temperament }\end{array}$ & $8(7)$ & $15(13)$ & $21(18.3)$ & $15(13)$ & $56(48.7)$ \\
\hline *Negative items requires reverse soring & & & \\
\hline
\end{tabular}

Table 2: Respondent's Attitude towards Communication of Student Nurse.

\section{Discussion of the Study}

The present study revealed that more than half $(67.8 \%)$ of the respondents were from 17-36 age group. The mean age \pm standard deviation $(34.18 \pm 13.42)$. Likewise, 59.1 percent of the respondents were male. Similarly, 48.7 percent of the respondents were from Janajati whereas, as only $5.2 \%$ of respondents were from Dalit ethnicity. In education 53.1 percent of respondents completed higher secondary and above degree whereas 8.7 percent of the respondents were illiterate. So on 54.8 percent of the respondents were from joint family. Most (93\%) of the respondents were from Hindu religion. In the same way, 67 percent of the respondents were married. Furthermore, most (83.5\%) of the respondents had more length of stay in hospital (Table 3). Likewise $30.4 \%$ of the respondents working as a labor. As well as, in economic status, 47 percent of respondents had just enough to run and have some medical expenses and 13 percent respondents had enough to run family but not for medical expenses. 
Page 3 of 5

\begin{tabular}{|l|l|l|l|l|l|}
\hline Items & Agree N (\%) & $\begin{array}{l}\text { Strongly Agree N } \\
(\%)\end{array}$ & $\begin{array}{l}\text { Neither agree } \\
\text { disagree N (\%) }\end{array}$ & $\begin{array}{l}\text { Strongly Disagree N } \\
\text { (\%) }\end{array}$ & Disagree N (\%) \\
\hline $\begin{array}{l}\text { In the presence of student I feel positively } \\
\text { motivated }\end{array}$ & $28(24.3)$ & $29(25.2)$ & $32(27.8)$ & $11(9.6)$ & $15(13)$ \\
\hline In the presence of student I feel disturbed & $11(9.6)$ & $13(11.3)$ & $40(34.8)$ & $23(20)$ & $28(24.3)$ \\
\hline $\begin{array}{l}\text { In the presence of student nurse there is more } \\
\text { small talk }\end{array}$ & $14(12.2)$ & $16(13.9)$ & $33(28.7)$ & $11(9.6)$ & $24(20.9)$ \\
\hline $\begin{array}{l}\text { In the presence of student the confidentiality of } \\
\text { nurse-patient relationship is compromised }\end{array}$ & $17(14.8)$ & $18(15.7)$ & $29(25.2)$ & $23(20)$ & $35(30.4)$ \\
\hline $\begin{array}{l}\text { The presence of student facilitates the discovery } \\
\text { of new information }\end{array}$ & $30(26.1)$ & $24(20.9)$ & $33(28.7)$ & $28(24.3)$ & $13(11.3)$ \\
\hline $\begin{array}{l}\text { My acceptance depends on students confidence } \\
\text { level }\end{array}$ & $34(29.6)$ & $18(15.7)$ & $37(32.2)$ & $16(13.9)$ & $8(7)$ \\
\hline $\begin{array}{l}\text { I prefer there to be no student nurses in the } \\
\text { hospital }\end{array}$ & $14(12.2)$ & $17(14.8)$ & $33(28.7)$ & $15(13)$ \\
\hline $\begin{array}{l}\text { Student nurse introduce themselves before } \\
\text { performing examination }\end{array}$ & $45(39.1)$ & $14(12.2)$ & $18(15.7)$ & $18(15.7)$ \\
\hline $\begin{array}{l}\text { *I do not like student nurses asking personal } \\
\text { questions regarding disease }\end{array}$ & $17(14.8)$ & $20(17.4)$ & $34(29.6)$ & $17(14.8)$ \\
\hline $\begin{array}{l}\text { Student nurses do not know anything about } \\
\text { patient disease }\end{array}$ & $13(11.3)$ & $27(23.5)$ & $25(21.7)$ & $16(13.9)$ \\
\hline *Negative items requires reverse soring & & & $22(19.1)$ \\
\hline
\end{tabular}

Table 3: Respondent's Attitude towards Presence of Student Nurse.

The present study showed, 24.3 percent of the respondents agree on positively motivated in the presence of students. The present finding is contrast with the study conducted by Mehta et al. [9] which showed 96.6 percent of the respondents agree on presence of nursing students in ward make the client positively motivated. Similarly, in present study, it was found that 26.1 percent of the respondents expressed the discovery of new information in the presence of students. In contrast to the present study done by Feedinand et al. [2] which showed that
88.6 percent of the patients have expressed, they were able to know more details about the illness from students and students helped in revealing details to the doctors (Table 4). Likewise, present study showed, 12.2 percent of the respondents agree that patient preferred no student's nurses in the hospital. In support to the present study conducted by Monnickendam et al. [12] which showed, only 3.2 percent of the respondents agree that patient objected to the presence of the nursing students in the ward.

\begin{tabular}{|l|l|l|l|l|l|}
\hline Items & Agree N (\%) & $\begin{array}{l}\text { Strongly Agree N } \\
(\%)\end{array}$ & $\begin{array}{l}\text { Neither agree nor } \\
\text { disagree N (\%) }\end{array}$ & $\begin{array}{l}\text { Strongly Disagree N } \\
\text { (\%) }\end{array}$ & Disagree N (\%) \\
\hline $\begin{array}{l}\text { Grade of nursing students differs the patient } \\
\text { care }\end{array}$ & $78(67.8)$ & $14(12.2)$ & $12(10.4)$ & $2(1.7)$ & $9(7.8)$ \\
\hline $\begin{array}{l}\text { Student nurse provides individualized care } \\
\text { based on their needs }\end{array}$ & $39(33.9)$ & $22(19.1)$ & $28(24.3)$ & $16(13.9)$ & $10(8.7)$ \\
\hline $\begin{array}{l}\text { Student nurse should be patience, cheerful and } \\
\text { empathetic while caring }\end{array}$ & $43(37.4)$ & $27(23.5)$ & $30(26.1)$ & $8(7)$ & $7(6.1)$ \\
\hline $\begin{array}{l}\text { *Patient did not really benefit from student } \\
\text { nurses on treatment process }\end{array}$ & $8(7)$ & $22(19.1)$ & $24(20.9)$ & $15(13)$ & $46(40)$ \\
\hline $\begin{array}{l}\text { Student nurse do not have so much experience } \\
\text { like the professional nurse }\end{array}$ & $47(40.9)$ & $25(21.7)$ & $27(23.5)$ & $9(7.8)$ & $7(6.1)$ \\
\hline $\begin{array}{l}\text { *Patient did not like student nurse examining } \\
\text { repeatedly taking a long time }\end{array}$ & $39(33.9)$ & $32(27.8)$ & $32(27.8)$ & $6(5.2)$ & $16(13.9)$ \\
\hline
\end{tabular}

Table 4: Respondent's Attitude towards Care Providing of Student Nurse. 
Page 4 of 5

Furthermore, the present study showed that 21.7 percent of respondents disagree with patients do not like student nurses asking personal questions regarding disease. In contradictory with the present study done by Cooke et al. which showed 95.5 percent of the respondents agree that they felt comfortable even discussing personal problem in front of students is encouraging. Similarly, the present study showed, 39.1 percent of the respondents agree that student nurse introduce themselves before performing examination. In support to the present study done by Debyser et al. [13] which showed that $52.4 \%$ of the respondents agree on nursing students introduce themselves before performing any procedure or examination in patients (Table 5).

\begin{tabular}{|l|l|l|}
\hline Variables & Frequency & Percentage \\
\hline Negative attitude (1-80) & 85 & 73.9 \\
\hline Neutral attitude (81) & 2 & 1.7 \\
\hline Positive attitude (82-135) & 28 & 24.3 \\
\hline
\end{tabular}

Table 5: Attitude of Patient towards Student Nurse.

In addition, the present study showed that 60.9 percent of the respondents agree with student's manner and appearances are important for patient's willingness to have them in care. In contrast to the present study, the study done by Abdulghani et al. [7] which showed 81 percent of the respondents agree that student's general appearance and manner were important to their willingness to have them participate in their care. Similarly, present study showed that 55.7 percent of the respondents agree that patient's satisfaction influenced by the appearance of the students. The present study is supported by the study done by Talal et al. [14] which showed that 56.7 percent of the respondents agree that general appearance and manner of the students will affect the level of their cooperation with students.

Moreover, in present study, it was found, 51.3 percent of the student's nurses are helpful, clean and tidy. In support to the study done by Mehta et al. [9] which showed that 50 percent of the respondents reported agree on students nurses are helpful, clean, and tidy, empathetic, soft spoken and unbiased. Furthermore, the present study showed nearly half (47.8\%) of the respondents agree that student nurse are identify through their dress code. In contradictory to the present study, the study done by Ferdinand et al. [2] which agrees that 80 percent of the respondents identify the student nurses through their dress code.

Furthermore, the present study showed that 23.5 percent of the respondents strongly agree that student nurses have more time to give. In contrast to the present study done by Mehta et al. [9] which showed, 51.7 percent of the respondents agree that students have more time for patient. Likewise, the present study showed that 48.7 percent of the respondents disagree with student nurses has good behavior and temperament. In contradictory to the present study conducted by Mehta et al. [9] which showed almost 93.2 percent of the respondents agree with student have good behavior and temperament.

Likewise, the present study showed that 36.5 percent of the respondents agree with student nurse behaves badly to the patients. In contrast with the present finding, the study done by Faronbi et al. [5] which revealed, 56.7 percent of the respondents agree with nursing students behave badly while caring patients. Likewise, the present study showed that 28.7 percent of the respondents neither agree nor disagree with patient enjoy caring and being student nurse. In contrast with the study done by Ramanayake et al. which showed that 88.6 percent of the patient's view that they rather benefitted from interacting with the patients and all the patients have enjoyed interacting with students [5].

Furthermore, the present study showed, 31.3 percent of the respondents agree with students nurses are skillful and competent in their nursing role. Similarly, the present finding was supported by the study done by Rima et al. [15] which showed that 41 percent of the respondents believe that student are skillful and competent in their nursing roles. Likewise, present study showed that 36.5 percent of the respondents neither agree nor disagree with student's nurses provide emotional support to patient. In contradictory to the present study done by Feedinand et al. [2] which showed that 66.5 percent of the respondents disagree with students nurse provides emotional support to the patients.

In addition, the present study showed that 67.8 percent of the respondents agree with grade of nursing students differs in patient care. In contrast to present study conducted by Onotai et al. [16] which showed that 80 percent of the respondents agree that nursing student's grade differ in patient care. Similarly, the present study revealed, 44.3 percent of the respondents agree that student nurse should be patience, cheerful and empathetic while caring. In contrast with the present study done by Farobin et al. [5] which revealed 97.2 percent of the respondents agree students nurses should be patience, cheerful, and sensitive as well as empathetic while caring patients.

Moreover, the present study showed that 31.9 percent agree on patient didn't like student nurse examining repeatedly taking a long time. The present study is contradictory with the study done by Mehta et al. [9] which revealed, 57.9 percent of the respondents agree that patient doesn't like repeated and longtime examination done by students nurse. Likewise, the present study showed nearly half (40.9\%) of the respondents responded student nurse do not have so much experience like the professional nurse. Present finding was contradictory with the study done by Feedinand et al. [2] which showed 80 percent of the respondents agree that nursing students are trainee; they do not have any experience like professional nurses. Likewise, the present study revealed that 33.9 percent of the respondents agree that student nurse provides individualized care according to their need. In contrast to the present study done by Simons et al. [17] which showed 65.8 percent of the respondents agree with students provides individualized care based on their needs [18-25].

\section{Result}

Most (73.9\%) of the respondents have negative attitude. Likewise, 24.3 percent of the respondents had positive attitude and 1.7 percent had neutral attitude towards student nurses.

\section{Conclusion}

The study shows least respondents disagreed towards the presence of nursing students in ward. Likewise, majority of the respondents agree that casual attire worn by students would impact on patient's confidence towards their involvement. In addition, minority of the respondents strongly disagreed that nursing students are skillful and competent in their nursing roles whereas least of the respondents disagree with the patients satisfaction influenced by student communication skill and behavior [26-33]. 
Page 5 of 5

On the basis of the finding of the study, it can be concluded that most of the respondents had negative attitude whereas only few had positive attitude towards nursing student.

\section{References}

1. World Health Organization (2017) WHO global report on nursing, Geneva. Switzerland.

2. Mukumbang FC, Oluyinka A (2014) Patients experiences of being nursed by student nurses at a teaching hospital. Journal of the Democratic Nursing Organization of South Africa 37: 1230-1236.

3. Rosseter R (2012) Media Relationship/Nursing Shortage. American Association of College of Nursing 202: 463-6930.

4. Salah AB, Mhamdi ES, Bounene L, Sriha A, Soltani M (2015) Patient's attitude towards bedside teaching in Tunisia. International Journal of Medical Education 6: 201-207.

5. Faronbi JO, Adebowale O, Faronbi GO, Musa OO, Ayamolowo SJ (2017) Perception knowledge and attitude of nursing students towards the care of older patients. International Journal of Africa Nursing Sciences 7: $37-42$.

6. Sayed-Hassan RM, Bashour HN, Koudsi AY (2012) Patient's attitudes towards medical students at Damascus University Teaching Hospital. Bio Medical Central Education 22: 13.

7. Abdulghani HM, Al-Rukban MO, Ahmad SS (2008) Patient attitudes towards medical students in Riyadh, Saudi Arabia. Education for Health 21: 69 .

8. Bromage SJ, Hu J, Ladds T, Robinson E, Pearce I (2007) Patient attitudes to nursing students in urology outpatients. International Journal of Urological Nursing 1: 120-125.

9. Mehta RS, Singh B (2013) Patient's attitude towards nursing students of B.P Koirala Institute of Health Sciences. Journal of Nepal Health Research Council 4: 145-154.

10. Gupta BS, Shrestha S, Thulung BK (2014) Patient's perception towards quality nursing care. Journal of Nepal Health Research Council 12: 83-87.

11. Mayr G, Nevill AM, Sami AS, Carmichael AR (2014) The Attitude of Patients towards the Presence of Medical Students in a Breast Clinic: A Self-Administered Questionnaire Based Audit. Journal of Health Education Research and Development 2: 1-5.

12. Monnickendam SM, Vinker S, Zalewski S, Cohen O, Kitai E (2008) Patients' attitudes towards the presence of medical students in family practice consultations. Israel Medical Association Journal 3: 903-906.

13. Debyser B, Grypdonck MH, Defloor T, Verhaeghe ST (2011) Involvement of inpatient mental health clients in the practical training and assessment of mental health nursing students: Can it benefit clients and students? Nurse Education Today 31: 198-203.

14. Talal AK, Sanaa BD, Basem ED (2016) Patients perception towards medical student's involvement in their surgical care. Education Research International, pp: 8-14.

15. Oluyinka MS, Hyam NB, Abir YK (2012) Patient attitudes towards medical students at Damascus University Teaching Hospital. Bio Medical Education 12: 13

16. Onotai LO, Asuquo EO, Amadi OA, Ali DU (2012) Patient's perception and attitude towards medical student's involvement in patient care at a Nigerian University Teaching Hospital. International Research Journals 3: 732-743.
17. Simons RJ, Imboden E, Martel JK (2010) Patient attitudes towards medical student participation in general internal medicine. Journal of General Internal Medicine 10: 251-254.

18. Atlanta (2012) Guideliness for professional appearance and attire for nursing students, 2017.

19. Bukhari I, AlAkloby O, Al Saeed W (2008) Patients'attitude towards Medical Students Rotating In the Dermatology Clinic. Indian Journal of Dermatology 53: 12.

20. Belete A, Lamaro T, Henok A (2015) Assessment of attitude towards nursing profession among nurses and non-nursing health professional working in mizan-aman general hospital. Southwest Ethiopia. Journal of Nursing and Care 6: 145-151.

21. Choudhury TR, Moosa AA, Cushing A, Bestwick J (2006) Patients' attitudes towards the presence of medical students during consultations. Medical Teacher 28: e198-203.

22. Getu MA, Gebru AA, Semaw BE (2015) Assessment of nurse's perception towards their profession and factors affecting it in Debre Berhan town government health institution, Debre Berhan, Ethiopia. American Journal of Nursing Science 4: 297-307.

23. Gilmore W, Avery DM, Tucker MT, Higginbotham JC (2016) Patients knowledge and attitudes of medical students and residents. Journal of Family Medicine and Community Health 3: 1075.

24. Al Ghobain M, Alghamdi A, Arab A, Alaem N, Aldress T, et al. (2016) Patients' perceptions towards the participation of medical students in their care. Sultan Qaboos University Medical Journal 16: e224.

25. Guitard V (2014) What is the difference between a student nurse and a student nurse employee. Information Nursing.

26. Islam F, Attar RE (2017) Effect of contact with patients on attitude of students nurses towards mentally ill. Journal of Socialomics 6: 211-219.

27. Midili TS, Kirmizioglu T, Kalkim A (2017) Affecting factors and relationship between patient's attitudes towards the nursing profession and perception of nursing care in a University Hospital. Journal of Pakistan Medical Association 67: 1059-1064.

28. Mora PM, Lal ES, Francescatti A, Hughes T, Hayden D, et al. (2013) What do patients think of medical students during their hospitalization. On institutions experience. United States National Library of Medicine National Institutes of Health 79: 1235-1237.

29. Michael D, Prislin MD, Elizabeth M, Mark G (2006) Patient's perception of medical students in a longitudinal family medicine clerkship. Medical Student Education 33: 187-191.

30. Mannickendam SM, Vinker S, Zalewski S, Cohen O, Kitai E (2006) Patient's attitudes towards the presence of medical students in family practice consultations. United States National Library of Medicine National Institute of Health, 3: 903-9036.

31. Oster C, Backtrom S, Lantz J, Ramkint M (2015) Psychiatric patient's perspectives of student's involvement in their care. Bio Medical Central Education 15: 69.

32. Santen SA, Hemphill RR, Spanier CM, Fletcher ND (2005) Sorry As my first time, Will patients consent to medical students learning procedure? Medical Education 39: 365-369.

33. Townsend B, Marks JB, Mauger DT, Miller JJ (2009) Patient's attitudes towards medical student's participation in a dermatology clinic. Indian J Dermatol 49: 709-711. 